\title{
NÁRODNÍ MUZEUM JAKO VYDAVATEL PERIODIK V LETECH 1918-1993
}

\author{
Klára Woitschová
}

\section{The National Museum as a Publisher of Periodicals}

\begin{abstract}
The publishing activity has been one of the important tasks of the National Museum since 1827, the year of the Journal of the National Museum's (Časopis Národního muzea) publication. The text describes the development of the Museum's publishing activities and covers their most significant features, such as working with internal and external authors, censorship, the internal mechanisms of publishing institute for specialized journals (the functioning of the editorial boards and the influence of the editors' personalities) at the National Museum and problems related with the journals' distribution to both the Czech, and foreign public. Attention is also paid to the technical difficulties involved in securing printing and sales of the museum's periodicals.
\end{abstract}

Keywords: National Museum - periodicals - editorial work - publishing house

Contacts: PhDr. Klára Woitschová, Ph.D., Archiv Národního muzea, Na Zátorách 6, 17000 Praha; klara.woitschova@nm.cz

\section{Úvod}

Národní muzeum jako významná vědecká a kulturní instituce již od svého založení v roce 1818 využívala celou řadu možností, jak komunikovat s veřejností, at' již laickou, či odbornou. Tím nejvýraznějším a nejvyužívanějším prostředkem $\mathrm{k}$ dialogu byla pochopitelně výstavní činnost, při níž byly všem zájemcům prezentovány výsledky sbírkotvorné činnosti, jiné sbírky byly spíše studijního charakteru a byly určeny pro specialisty jednotlivých oborů. Četní zaměstnanci Národního muzea (dále Muzea či NM) také prezentovali výsledky své vědecké činnosti prostřednictvím veřejných přednášek, jejichž tematická paleta byla široká, stejně jako byl bohatý rozptyl sbírek, které Muzeum pod svou střechou schraňovalo. Přednášky se konaly jak na našich i zahraničních univerzitách, tak v regionálních muzeích či při různých př́ležitostech i před poučeným posluchačstvem. Muzeum dávalo o sobě vědět také prostřednictvím nejrůznějších typů médií, nejprve pochopitelně těch tištěných (novin, časopisů, knih), později také využívalo rozhlasového a televizního vysílání a občas i filmového pásu. Z širokého spektra komunikačních kanálů s veřejností bude v následujícím textu věnována pozornost především tištěným výstupům, konkrétně odborným časopisům, které Muzeum vydávalo.

Sílu tištěného slova a jeho možný dopad na odbornou i laickou veřejnost si uvědomovali čelní představitelé Národního muzea již od samotného jeho založení. Muzeum a jeho představitelé komunikovali pravidelně s různými novinami, které uveřejňovaly o přední české muzejní instituci pravidelné zprávy. Některé z nich dodávalo samo Muzeum. Ty pochopitelně vždy vyznívaly vůči Muzeu pozitivně, informovaly o vzácných prírůstcích či poutaly na zajímavé výstavy či přednášky. Novinové články, které vznikly z iniciativy reportérů či dokonce samotných muzejníků, naopak poukazovaly na méně prŕijemné stránky muzejního života, nedostatek financí i prostoru, na nešvary muzejních zaměstnanců a podobně. Známe však také přinejmenším jeden případ, kdy i negativní „reklama“ v novinách měla zcela pozitivní výsledek, a sice 1. března 1918, kdy se v reakci na článek o finančních potížích Společnosti NM, která Muzeum tehdy spravovala, rozpoutala vlna solidarity a počet členů Společnosti tehdy stoupl takřka o tisíc osob. Související prríliv financí zachránil v těžké válečné situaci existenci Národního muzea vskutku v poslední chvíli. Takto pozitivní vyznění však bylo spíše výjimečné a častější bylo následkem interní vyšetřování v Muzeu a př́ípadně i postihy zaměstnanců, případně zákazy komunikovat s novináři bez vědomí vedení instituce. Nicméně analýzu denního tisku ve vztahu k Muzeu ponecháváme $\mathrm{v}$ této stati stranou, nebot' se jedná o zcela specifické téma s odlišnou pramennou základnou a jinou metodologií.

Pozornost v tomto textu bude upřena na vydávání muzejních časopisů, a to především v období existence samostatného Československa (1918-1992). Uvedené časové vymezení bylo zvoleno vzhledem $\mathrm{k}$ tomu, že teprve ve druhém století existence Muzea můžeme na tomto poli muzejní činnosti sledovat dynamičtější rozvoj, tj. pomalu narůstal počet časopisů vydávaných pod patronací Muzea a tato činnost získávala postupně svá pevná pravidla.

Ještě než se budeme zabývat konkrétní problematikou, podívejme se podrobněji na prameny, na jejichž základě je možno tuto problematiku studovat. Kupodivu se z hlediska pramenného jedná o poměrně obtížně uchopitelné téma. Na prvním místě je třeba konstatovat, že s jedinou výjimkou neexistují kontinuálně dochované redakční archivy

1 Text vznikl v rámci projektu Grantové agentury ČR „Národní muzeum v éře Československa“ č. GA16-02022S. 
jednotlivých časopisů. ${ }^{2}$ Pravděpodobně to je způsobeno tím, že většinu redakční práce obstarávala externí nakladatelství, jak o tom bude ještě podrobněji řeč níže. Tyto nakladatelské domy však dnes již neexistují, resp. jejich archivy (dochované nadto pouze zlomkovitě) jsou v současné době nedostupné. ${ }^{3}$ Při neexistenci archivů jednotlivých redakcí je třeba spoléhat se pouze na materiály všeobecně zaměřené muzejní registratury. ${ }^{4}$ Zpracování dějin jednotlivých časopiseckých titulů vydávaných Muzeem je v sekundární literatuře sledováno pouze naprosto výjimečně a okrajově. Pozornost na sebe pochopitelně poutal Časopis Národního muzea coby vlajková lod' muzejních periodik a výjimečně i některé další, na jejichž vydávání se Muzeum různou formou podílelo. ${ }^{5}$

Vydávání časopisů v Muzeu bude na následujících stránkách sledováno z celé řady aspektů. Po krátkém představení portfolia časopisů a sborníků vydávaných Muzeem bude věnována pozornost konkrétním aspektům muzejní vydavatelské činnosti, jako byly kooperace s jinými nakladatelskými organizacemi, financování časopisů, vývoj vnitřních mechanismů (např. krystalizace redakčních rad) či technickým problémům (nedostatek papíru a tiskárenských kapacit, potíže s distribucí).

K úvodní pasáži je na závěr ještě třeba připojit drobný terminologický exkurz, nebot' někdejší a současné charakteristiky jednotlivých v Muzeu pravidelně vycházejících tisků je disparátní. Zatímco dnes je za periodikum na základě tiskového zákona ${ }^{6}$ striktně brána pouze publikace vycházející „pod stejným názvem, se stejným obsahovým zaměřením a v jednotné grafické úpravě nejméně dvakrát v kalendářním roce“, v muzejní terminologii se pojmem periodikum označovaly i ty tisky, které sice vycházely pravidelně, nicméně pouze jednou ročně. Pod pojmem sborník se pak v Muzeu rozuměly takové tisky, které vycházely s nepravidelnou periodicitou (tj. podle toho, jak se jednotlivé díly podařilo naplnit, což mohlo být jak vícekrát za rok, tak pouze jednou za několik let). Na tyto zvláštnosti bude níže v textu upozorněno.

\section{Periodika Národního muzea}

Když František Palacký prosadil v roce 1827 v Národním muzeu pravidelné vydávání odborného českého časopisu, tedy Časopisu Společnosti vlastenského museum v Čechách, neformálně nazývaného Muzejník, ${ }^{7}$ jednalo se o úplnou novinku, jejíž uskutečnění bylo v muzejních poměrech poměrně komplikované. A to ani ne personálně, vzhledem k tomu, že celá řada tehdejších pracovníků Muzea byla aktivními publicisty a s tímto problémem by si jistě byli schopní poradit bez větších obtíží, ale jako ve všech ohledech své činnosti, narážela Společnost NM (která byla v té době majitelkou a správkyní NM) na nemalé finanční i organizační obtíže. Muzeum tedy vydalo ve své vlastní režii pouze prvních několik ročníků Časopisu a poté v roce 1831 jeho vydávání předalo nově vzniklé Matici české. Jen připomeňme, že se jednalo o jeden $\mathrm{z}$ odborných sborů zř́zzených při NM pod názvem Sbor k vědeckému vzdělání řeči a literatury české, jemuž byl svěřen i fond pro podporu vydávání kvalitních českých knih. Celému sboru se pak pro jednoduchost říkalo podle tohoto fondu Matice česká. ${ }^{8} \mathrm{Ta}$ ve vydávání časopisu pokračovala až do poloviny 20 . století.

Úloha Matice byla v ediční politice Muzea až do zrušení jejího nakladatelského oprávnění zcela nezastupitelná. Obě korporace existovaly sice do jisté míry samostatně a byly financovány zvlášt', nicméně úzce kooperovaly, $\mathrm{v}$ jejích orgánech byli často zastoupení muzejní pracovníci. Není nikterak přehnané, řekneme-li, že Matice česká působila jako „dvorní“ nakladatel většiny tisků, které vyšly z Muzea a byly určeny veřejnosti. Muzeum pochopitelně na vydávání svých knih a časopisů Matici přispívalo určitými částkami a tyto př́ispěvky se týkaly i dalších časopisů, které byly vydávány jinými vědeckými sbory Muzea. Př́rodovědecký sbor NM tak vydal v roce 1853 první číslo časopisu Živa (hlavním aktérem této aktivity byl Jan Evangelista Purkyně), který s jistými přestávkami a mnohými obsahovými i formálními změnami vychází dodnes, o rok později započal Archeologický sbor NM s vydáváním (později pokračoval jako spoluvydavatel) dodnes též existujících Památek archeologických a místopisných. O tom, že NM dlouhodobě mělo obtíže s plnění svých závazků vůči vydavatelům těchto časopisů, svědčí např. žádost redakce Památek, aby jí bylo okamžitě vyplaceno Archeologickým sborem 600 korun a samým NM 400 korun s odůvodněním, že ,jest s podivem, že tato nepatrná subvence ani za poslední léta nebyla vyplacena, ačkoliv Památky veliké služby pokazuji museu “. 9 .

Na nastaveném modu vivendi mezi Muzeem a Maticí se pak mnoho nezměnilo ani v první části období, na něž je primárně tento text zaměřen, tedy $\mathrm{v}$ době po vzniku samostatného Československa. V roce 1918 stále ještě existoval pouze jediný časopis vydávaný Muzeem (nikoli některým z jeho sborů), a sice Časopis Musea království Českého, který si, mimochodem, tento svůj název podržel až do roku 1922. V předválečných letech prošlo periodikum bouřlivým

\footnotetext{
2 Tuto výjimku představuje redakce jednotlivých řad Sborníku Národního muzea, jejíž materiály jsou vyčleněny v archivním fondu Archivu Národního muzea (dále ANM) fond (dále f.) Registratura Národního muzea - Sborník Národního muzea - redakce (1962-2006), 2,65 bm, nezpracováno.

3 Jedná se např. o podnikové archivy nakladatelství Orbis a Panorama (oba jsou uloženy v Národním archivu, resp. Státním oblastním archivu Praha, nicméně jsou neuspořádané).

${ }^{4}$ Z konkrétních fondů jmenujme Archiv Národního muzea, f. Registratura Národního muzea (dále RNM), př́ípadně její samostatné části ANM, f. RNM, či RNM, Sekretariát GŘ atd.

${ }_{5}^{5}$ Nejnověji srv. jubilejní 100. ročník časopisu Český lid, kde je možné nalézt stati věnované těmto časopisům i se souhrnem starší literatury: Klára Wortschová, Casopis Národního muzea v letech 1827-2012, Český lid, 2013, roč. 100, č. 1, s. 5-25; Michal ErNée, Památky archeologické - po 160 letech stále na rozcestí, Český lid, 2013, roč. 100, č. 1, s. 27-50 a Karel Sklenár̆, Sto dvacet let Časopisu Společnosti prátel starožitností, Český lid, 2013, roč. 100, č. 1, s. 99-106.

${ }^{6}$ Tiskový zákon č. 46/2000 Sb., vymezení pojmů v §3, odst. a). Podobně byla definice periodika ošetřena i v předcházejícím tiskovém zákoně č. 81/1966 Sb. Ve starší tiskové legislativě (č. 184/1950 Sb.) se tyto definiční otázky neřešily.

7 Název časopisu se později několikrát změnil, čtenáři jej znali např. jako Časopis Českého museum. Po dalších (často kosmetických) úpravách názvu dnes periodikum nese název Časopis Národního muzea (vychází ve dvou řadách - historické a př́rodovědné).

${ }^{8}$ Ze starší literatury k Matici české můžeme uvést např. Karel TiEFTRUnK, Dějiny Matice české: z uložení užšího sboru musejního pro řeč a literaturu českou, Praha 1881 a z novějších např̀. v širším kontextu Eva RYšAvÁ, Matice česká v našich kulturních dějinách, in: Dějiny Moravy a Matice moravská: problémy a perspektivy. Sborník př́spěvků z vědecké konference konané ve dnech 24.-25. listopadu 1999 v Brně, Brno 2000, s. 47-51.

9 ANM, f. RNM, k. 99, List redakce Památek archeologických správě NM, 18. 12. 1922.
} 
obdobím, které v roce 1914 vyvrcholilo odvoláním redaktora Čeňka Zíbrta, a započala cesta k oddělování společenskovědní a přírodovědné větve časopisu završená v roce 1918. S úrovní časopisu však ani v následujících letech nepanovala mezi odbornou veřejností spokojenost - mezi redaktory nebyly silné osobnosti, které by vtiskly periodiku jednoznačný charakter, problémy přinášela i neoddiskutovatelná rivalita Muzea s univerzitními pracovišti a ČAVU, která se bohužel projevovala setrvalým zaostáváním muzejní vědy především ve společenskovědních oblastech. ${ }^{10}$

Pouze ve výjimečných případech se v období první republiky Muzeum pouštělo do samostatných vydavatelských projektů. Obecně můžeme říci, že se vždy jednalo o publikace, které měly v očích představitelů instituce značný prodejní či výměnný potenciál, který se jim zdál jako dostatečná kompenzace za velmi komplikovanou anabázi zisku financování těchto titulů, na vydání obsáhlého spisu Národní museum a naše obrozeni Josefa Hanuše a Pravěku země české Albína Stockého bylo totiž třeba žádat zvláštní (a nemalou) subvenci ze strany země České. ${ }^{11}$ Kupodivu se i za cenu obdobné administrativní zátěže Muzeum rozhodlo ve vlastní režii (s podporou výnosů Nickerlova fondu) ${ }^{12}$ vydávat od roku 1923 svůj druhý odborný časopis, v tomto př́ípadě úzce specializovaný, a sice Acta Entomologica Musei Nationalis Pragae. ${ }^{13}$ Připomeňme jen, že volba specializace nebyla náhodná a entomologická sbírka byla jednou z nejprogresivněji se rozvíjejících př́rodovědných sbírek NM.

Ještě do meziválečného období spadá vznik dalšího významného muzejního periodika, a sice Sborníku Národního muzea. K čemu Muzeum potřebovalo při existenci Muzejníku další časopis? Odpověd' na tuto otázku může být v zásadě dvojí: první problém tkvěl v tom, že s postupujícími lety bylo tíźivě pocit’ováno odcizení mezi Muzeem a jeho časopisem. Rozhodující vliv na časopis si totiž z praktických důvodů přivlastnila Matice česká a ovlivňovala nejen výběr osoby, která stála v čele časopisu, ale také výběr autorů a celkové směřování periodika. Zároveň byly vzhledem ke změnám v samotném Muzeu (od roku 1935 přešlo do majetku země České) ne zcela jasné vztahy Muzea a Matice. Muzeum tak sice mělo fakticky stále svůj starobylý časopis, nicméně na jeho osudy mělo jen slabý vliv. ${ }^{14}$ Druhým popudem ke vzniku nového časopisu pak byl fakt, že Muzejník se změnil spíše v populárně-naučný časopis a mezi muzejními kurátory se zvýšila poptávka po vlastním čistě vědeckém periodiku určeném pro publikování rozsáhlejších vědeckých studií. Tím se měl stát právě nově zakládaný druhý časopis. Jak si 15. 2. 1937 radostně zapsal do svého deníku Josef
Volf, tehdejší ředitel Knihovny NM, ,bylo usneseno, aby úředníci vydávali svioj časopis Annály Nár. Musea, který by sami redigovali... Knihovna prevezme administraci. Budou 2 nebo 1 hlavní redaktor, což se teprve rozhodne. Vúřednictvu mimo knihovnu velká radost... "15

Podle směrnice pro vydávání nového časopisu měl tento nést název Sborník Národního muzea neboli Acta Musei Nationalis Pragae a jeho hlavním úkolem bylo reprezentovat muzejní vědu doma a především v zahraničí. Obsahově se měl zaměřovat především na obory v NM zastoupené a především na jeho sbírky. Na stránkách Sborníku se předpokládal tisk rozsáhlých a významných studií. Publikovat se mělo sice v češtině a slovenštině, ale s ohledem na zahraničí se počítalo s rozsáhlými cizojazyčnými resumé. Časopis měl podobně jako Muzejník vycházet ve dvou řadách, prrírodovědné a historické, přičemž domácí charakter časopisu podtrhovalo ještě to, že členy redakčních rad byli vedoucí př́íslušných oddělení NM. O administrativní zajištění výroby časopisu a o jeho distribuci se měly dělit administrativní kancelář a Knihovna NM. ${ }^{16}$ Jen podotkněme, že dnes by byla taková institucionální uzavřenost časopisu vnímána negativně, dobová měřítka však byla přece jen jiná a cílem NM v tuto chvíli bylo skutečně založení vlastního časopisu pro domácí autory.

Nový časopis však sotva stihl vydat svá první čísla, když do vývoje Muzea zasáhly události „velkých dějin“ a České země byly okupovány a o několik měsíců později vypukla II. světová válka. Instituce byla nucena řešit celou řadu existenciálních problémů, postupně se stupňoval útlak okupačních orgánů, NM se potýkalo se s omezeným financováním a zvýšenými nároky na ochranu sbírek a další vývoj ediční činnosti byl pochopitelně $\mathrm{v}$ této situaci zbrzděn. V roce 1941 pak bylo na základě nařízení vlády 175/1941 Sb. z. a n. o úpravě poměrů v českém tisku ze dne 7 . května vydávání všech muzejních časopisů zastaveno, a to s poukazem na nedostatek papíru. ${ }^{17}$ Je zřejmé, že oficiální zdůvodnění sice odpovídalo skutečnosti (papíru byl skutečně v důsledku hospodářských omezení nedostatek), hlavní příčinou však bylo to, že podpora české vědy a kultury nebyla v žádném př́ípadě v zájmu okupačních úřadů.

Po skončení druhé světové války, jakmile se podařilo zahladit nejpalčivější materiální škody na muzejních budovách i inventáři, se prrikročilo i k obnovení muzejní tiskové produkce. $\mathrm{K}$ válečné pauze přistoupil každý z časopisů jinak: zatímco Muzejník přiznává pauzu, Sborník Národního muzea postupně vydal i válečná čísla. Jakkoli se podle vročení poválečných ročníků může zdát, že návrat ke starým pořádkům nastal prakticky ihned, ve skutečnosti byla první

\footnotetext{
${ }^{10}$ Detailně srv. př́slušné pasáže in K. WortschovÁ, Časopis Národního muzea v letech 1827-2012.

${ }^{11}$ Josef Hanuš, Národni museum a naše obrození. Kniha 1. Kulturní a národni obrozeni šlechty české v 18. a v prvé pưli 19. století. Jeho význam pro založení a počátky musea, Praha 1921 a Josef Hanuš, Národní museum a naše obrození. Kniha 2. Založení vlasteneckého musea v Čechách a jeho vývoj do konce doby Šternberkovy (1818-1841), Praha 1923; Albín SтоскÝ, Pravěk země české I - Věk kamenný, Praha 1926.

${ }^{12} \mathrm{~V}$ období první republiky byly kromě př́íspěvků ze státního a zemského rozpočtu jedním ze zdrojů muzejních př́imů i výnosy z několika fondů zř́zených soukromými osobami, většinou příznivci Muzea. Otakar Nickerl (1838-1920), český lékař, botanik a entomolog, muzeu odkázal nejen své rozsáhlé entomologické sbírky, ale také značnou finanční částku, jejíž výnosy měly být používány pro financování vydávání entomologických prací založených na muzejních sbírkách a také $\mathrm{k}$ podpoře badatelských cest konaných $\mathrm{v}$ tomto oboru.

${ }^{13}$ Vydání prvního čísla časopisu hlásil Presidiu Národního muzea přednosta zoologického oddělení Václav Vávra dne 18. prosince 1923. (ANM, f. RNM, k. 99, č. j. 936).

${ }^{14}$ Zoroslava DroBnÁ, Vývoj programu a posláni Časopisu Národního muzea za sto padesát let jeho trvání, Časopis Národního muzea - řada historická, roč. 146, 1977, s. 28-29.

${ }^{15}$ ANM, f. Volf Josef, Deník, 15. 2. 1937.

${ }^{16}$ ANM, f. RNM, 1937, sig. S/Č1, spis Časopis Národního musea a Sborník Nár. musea.

${ }^{17}$ Jiří ŠPÉT, Historie v Časopise Národního muzea, Časopis Národního muzea - řada historická, roč. 146, 1977, s. 131.
} 


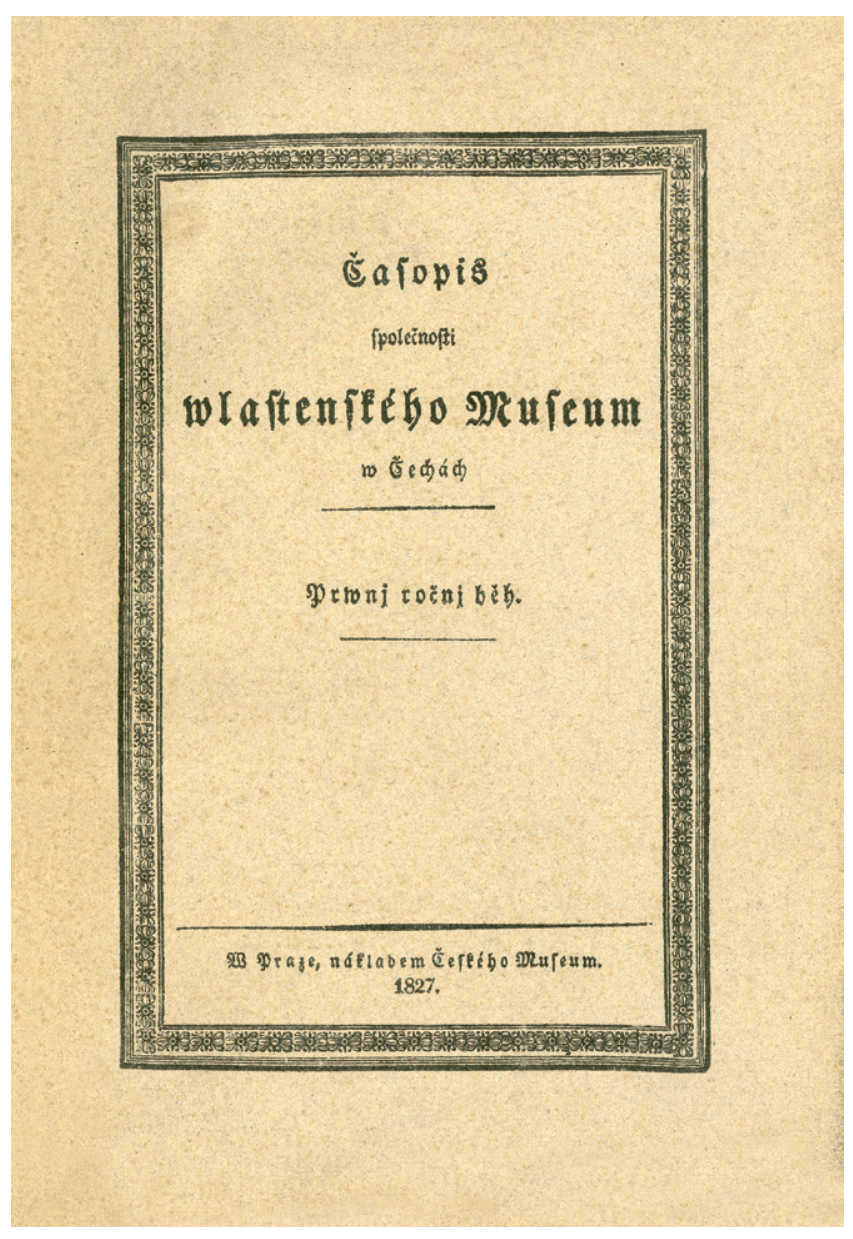

Obr. 1. Národní muzeum se v roce 1827 stalo vydavatelem našeho nejstaršího kontinuálně vycházejícího periodika, Časopisu Společnosti vlastenského Museum v Čechách.

poválečná čísla (či ta válečná) dovydávána postupně v letech 1946-1948.

Již období tzv. třetí Československé republiky naznačovalo změny vnitřní politické linie a zahraničně-politické orientace a tyto tendence se pak vyhrotily po roce 1948 . Veškerá činnost kulturních institucí byla podřizována silnému centrálnímu dohledu a věnujeme-li se v tomto textu vydavatelským a publikačním aktivitám jednotlivců i institucí, tak právě v těchto oblastech se vliv ústředních institucí, ideologický tlak a cenzurní zásahy projevují obzvláště silně. Přítomnost těchto vlivů na vydávání monografických publikací, katalogů i periodik je v Národním muzeu neoddiskutovatelná, přesto si však instituce po celou dobu ve všech těchto oblastech udržela vysokou profesionalitu a odbornou kvalitu. ${ }^{18}$

Na první pohled se toho ve vydavatelské muzejní praxi mnoho nezměnilo, poválečné období presto znamenalo pro vydávání časopisů v Muzeu zásadní změnu. Matici české byla odňata možnost věnovat se vydavatelské činnosti (k roku 1952) a formálně se mělo stát vydavatelem samotné
Muzeum, v praxi ovšem byla vydavatelská činnost delegována postupně na Státní pedagogické nakladatelství, později na nakladatelství Orbis a Panorama. Odbornou stránku věci však garantovalo Muzeum a z řad jeho zaměstnanců také byli jmenováni členové jednotlivých redakčních rad.

V 50. a 60. letech došlo po poválečné konsolidaci vnitřních muzejních poměrů $\mathrm{k}$ výraznějšímu obohacení palety vydávaných časopisů. Svým dílem přispěly různé součásti Muzea: jednak př́rodovědci zahájili vydávání časopisu Lynx (v roce 1962), po druhé válce definitivně k NM připojené Náprstkovo muzeum v témže roce založilo své Annals of the Náprstek Museum. Hned v roce následujícím pak spatřilo světlo světa první číslo Muzejní a vlastivědné práce.

Vydávání Muzejní a vlastivědné práce si vyžaduje přece jen podrobnějšího vysvětlení. Vydavatelem byl Kabinet muzejní a vlastivědné práce (později Ústřední muzeologický kabinet), který fungoval (po provozní stránce) v rámci Národního muzea, avšak zároveň i mimo něj, protože jeho bezprostředně nadřízeným orgánem bylo prrímo ministerstvo kultury. Vzhledem k tomu se v časopise zejména v dobách normalizace koncentrovaly ideologicky zaměřené texty týkající se českého muzejnictví a muzeologie. ${ }^{19}$ Muzejní a vlastivědná práce zároveň pohltila jiné tradiční periodikum, a sice Časopis Společnosti práátel starožitností (českých) - ze staršího časopisu zůstalo pouze číslování ročníku a část názvu, obsah byl víceméně kompletně podřizen zájmům a ideologickému zaměření Kabinetu. ${ }^{20}$ Zároveň je nutno připomenout, že časopis byl v periodicitě čtyřri krát ročně dodáván do všech muzeí v tehdejší republice, odtud tedy můžeme vyvozovat, že se jednalo o bezkonkurenčně nejvlivnější a nejrozšířenější periodikum vydávané NM, samozřejmě míněno v hranicích tehdejší Československé (socialistické) republiky.

V 50. a 60. letech minulého století doplnilo pravidelně vycházející časopisy i několik sborníků či monografických sérií (v podstatě však byly i tyto řady do jisté míry vnímány jako svého druhu časopisy), jako byly Fontes archaeologici pragenses (od roku 1958), Acta faunistica Musei Nationalis Pragensis (od 1957), Prameny k dějinám českého divadla (1964), Průvodce pravěkem (1966) či řada Inventáře a katalogy zpřístupňující zájemcům bohatství sbírkových a archivních celků uložených v NM.

Vznikem těchto titulů můžeme považovat vývoj portfolia muzejních periodik $\mathrm{v}$ podstatě za dokončený a $\mathrm{v}$ následujících desetiletích došlo již jen k několika pokusům o jeho reformování, resp. rozšíření.

V první řadě usilovalo již minimálně od roku $1978^{21}$ pochopitelně o vlastní časopis i do Národního muzea nově včleněné Muzeum české hudby, přičemž základní představa byla, že ke Sborníku bude přidána další oborově koncipovaná řada, založení nového časopisu však nebylo pouze na iniciativě NM, ale znamenalo rozsáhlý administrativní problém, včetně jednání s nakladatelstvím Panorama, ministerstvem kultury a Českým úřadem pro tisk a informace. ${ }^{22}$ Byt'

\footnotetext{
${ }^{18}$ Hůře na tom byla drobná regionální muzea, která byla pod přímým vlivem okresních či krajských národních výborů a často byli jejich vedením pověrováni vysloužilí či již nepohodlní funkcionáři KSČ.

${ }^{19}$ Podrobněji srv. K. SkLenÁř̆, Sto dvacet let, s. 103.

${ }^{20}$ Časopis tedy vycházel pod názvem MVP / ČSPS a rovněž s lomeným číslováním.

${ }^{21}$ ANM, f. RNM, Sekretariát GŘ 1982, Vnitroústavní sdělení ředitele ČMH 20. 12. 1987 řediteli NM, v němž se počítalo se zahájením vydávání muzikologického časopisu již od ledna roku 1981

${ }^{22}$ ANM, f. RNM, Sekretariát GŘ, 1981, Zápis ze schůze Ediční rady konané dne 30. 7. 1981, bod 4; Zápis ze schůze Ediční rady NM ze dne 4.6. 1981. Český ústav pro tisk a informace byl před rokem 1989 cenzurním úřadem, jehož schválení podléhalo i zřizování nových časopisů.
} 

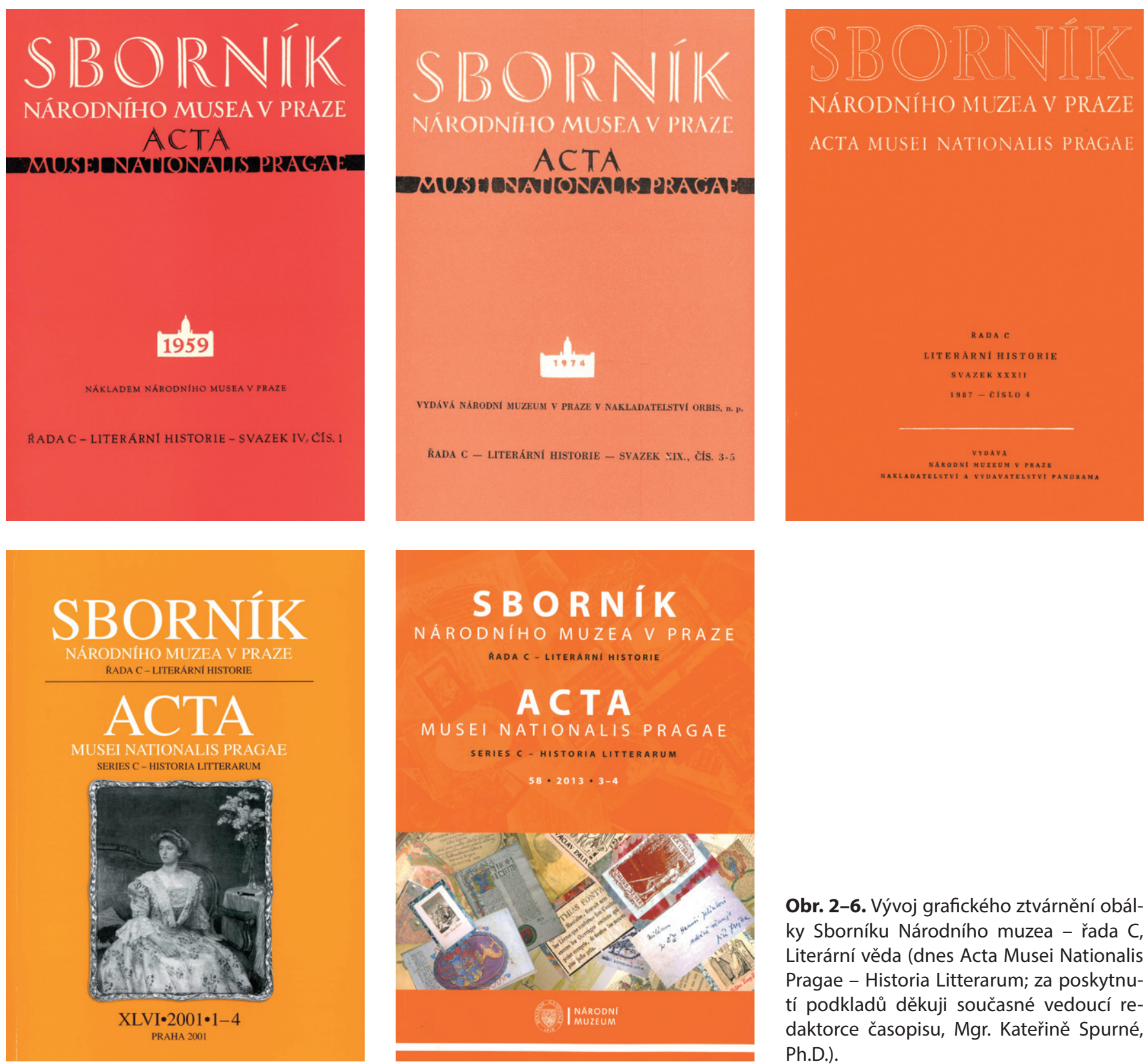

Obr. 2-6. Vývoj grafického ztvárnění obálky Sborníku Národního muzea - řada C, Literární věda (dnes Acta Musei Nationalis Pragae - Historia Litterarum; za poskytnutí podkladů děkuji současné vedoucí redaktorce časopisu, Mgr. Kateřině Spurné, Ph.D.).

tato aktivita vypadala velmi nadějně, nakonec ke vzniku nové řady nedošlo a pracovníci ČMH byli nakonec bez dalšího odkázáni na publikování v ostatních společenskovědních časopisech NM. ${ }^{23}$

Autorem dalšího z návrhů na změnu byl Jiří Špét (významný pracovník Kabinetu), který předpokládal transformaci téměř všech muzejních časopisů do specializovaných řad Sborníku NM $\mathrm{NM}^{24}$ (měla tedy přibýt řada D pro muzikologii, řada $\mathrm{E}$ pro mimoevropskou kulturu). Zatímco pro pracovníky Muzea české hudby by taková změna znamenala naplnění jejich dlouhodobého přání, v Náprstkově muzeu vzbudil návrh značné (a pochopitelné) rozpaky, nebot' by museli výrazně proměnit své Annals, které byly v té době již respektovaným a zavedeným periodikem a požívaly prestiže i daleko za hranicemi Československa. Vedení Náprstkova muzea tedy strategicky podmínilo svi̊j souhlas s navrhovanou reformou zejména tím, že zrušení do té doby vycházejících časopisů se bude týkat i těch, které byly vydávány Př́rodovědeckým muzeem. Síla námitek Př́rodovědeckého muzea byla $\mathrm{v}$ tomto př́padě značná a nepřekonatelná (s čímž jistě ředitel Náprstkova muzea V. Šolc kalkuloval koneckonců výhrady muzejních prŕrodovědců byly obsahově obdobné) a ani tento návrh nebyl uskutečněn. ${ }^{25}$

V roce 1989 se pak objevila ještě poslední výrazná reformní iniciativa, tentokrát směrující $\mathrm{k}$ přeměně historické řady Časopisu Národního muzea. Šlo o plány vskutku velkorysé. Tehdejší ředitel Historického muzea Vlastimil Vondruška ve spolupráci s redaktorem ČNM Jaroslavem

\footnotetext{
${ }^{23}$ ANM, f. RNM, Sekretariát Gř, 1985, Zápis Ediční rady národního muzea, která se konala 21. 11. 1985, bod 2c.

${ }^{24}$ Jen stručně připomeňme - Časopis Národního muzea (později ve dvou řadách specializovaných na společenské a př́rodní vědy) bylo periodikum určené pro oborově pestré kratší odborné texty, recenze, zprávy o činnosti atd.), zatímco jednotlivá čísla a řady Sborníku NM měly být pojaty bud' čistě monograficky, nebo alespoň monotematicky. Stejný charakter si obě periodika zachovávají od svého založení dodnes.

${ }^{25}$ ANM, f. RNM, Sekretariát GR̃, 1985, Návrh Jiř́ího Špéta.
} 
Čechurou navrhovali mnohonásobné zvýšení nákladu ČNM, jeho tisk v barvě a distribuci prostřednictvím stánků Poštovní a novinové služby. Cílovou skupinou čtenářů měli být laičtí čtenáři se zájmem o historii, znamenalo by to ovšem kompletní přeměnu časopisu na populárně-naučný, či snad dokonce pouze populární. Politické změny v listopadu 1989 však tuto změnu zablokovaly. ${ }^{26}$

$\mathrm{V}$ textu byly dosud zmíněny časopisecké tituly, které Muzeum vydávalo ve vlastní režii a byla také zmíněna praxe spolupráce s různými externími vydavatelstvími. V Národním muzeu však ještě existoval jeden specifický model vydávání časopisů, a to $\mathrm{v}$ těsné spolupráci s různě zaměřenými odbornými společnostmi. Prvním takovým př́ípadem byla kooperace s Československou (od r. 1970 Českou) numismatickou společností, jejímž výsledkem byl časopis Numismatické listy, druhým pak byl časopis Sylvia, který vycházel v návaznosti na kooperaci Muzea a České společnosti ornitologické (NM bylo vydavatelem od roku 1970). Spolupráce s odbornými společnostmi vnášela do vydávání obou titulů některé skutečnosti, at' již pozitivní, či negativní, o nichž ještě bude učiněna podrobnější zmínka níže v textu.

Podzim roku 1989 navrátil Československo k demokratickému zřízení. Pro Národní muzeum se otevřely nové možnosti, instituce však v nových poměrech musela čelit nečekaným výzvám. Odstranění ideologických nánosů z expozic bylo relativně snadné, přizpůsobit se poměrům vznikající tržní ekonomiky bylo mnohem složitější. Prudký nárůst cen a nové publikační strategie dosud víceméně bezproblémově spolupracujících nakladatelství značně komplikovaly snahu Muzea o udržení původního portfolia časopisů. Vydávání periodik se zpožd'ovalo, v některých př́padech byl počátkem 90. let redukován počet vydaných čísel jednotlivých titulů. S jistým časovým odstupem je však možno říci, že se s těmito výzvami Národní muzeum dokázalo vyrovnat se ctí. Po stabilizaci situace se pak dokonce řada muzejních periodik začala znovu rozrůstat.

\section{Vnitřní mechanismy fungování muzejních časopisů}

V průběhu 20. století můžeme sledovat modernizaci fungování muzejních časopisů. Na počátku století byl jediný tehdy vycházející časopis, Muzejník, řízen v podstatě monokraticky, tj. rozhodující slovo ve všech ohledech měl vedoucí redaktor. $\mathrm{V}$ případě Muzejníku můžeme v této souvislosti připomenout zejména dominantní osobnost redaktora Čeňka Zíbrta (spoluredaktorem v letech 1899-1904, samostatným redaktorem 1905-1913), který nejen že určoval, které články vyjdou a které nikoliv (a v podstatě bez jakékoli kontroly tak určoval vývoj a náplň časopisu), ale suverénně zasahoval i do samotných textů, které svévolně měnil i bez souhlasu autorů. Po těchto zkušenostech se pak ve vedení Muzejníku již většinou objevovalo více osob zároveň. Těsně před druhou světovou válkou už stála $\mathrm{v}$ čele skupina tří vědců (Jaroslav Prokeš, Gustav Skalský a Václav Vojtíšek), v př́ípadě nově zakládaného Sborníku NM vidíme již od počátku klasickou několikačlennou redakční radu. K podobnému schématu vedení časopisů se pak vrátilo Muzeum i po druhé světové válce a napodobilo jej i u všech nově vzniklých periodik i sborníků. Členy redakční rady byli zprvu především pracovníci Národního muzea, postupem času začali být jmenováni i pracovníci dalších předních vědeckých a kulturních institucí, především univerzit či ústavů Československé akademie věd. $\mathrm{V}$ průběhu 2. poloviny 20. století také byl ustaven centrální orgán, jenž měl koordinovat ediční činnost v celém Národním muzeu, ediční rada. Zatím se nepodařilo v pramenech nalézt konkrétní dokumenty související s jejím založením, zdá se však, že první takový orgán fungoval od druhé poloviny 60. let minulého století. V roce 1972 se pak výslovně mluví o jejím obnovení a od té doby se také pravidelně rada scházela na pravidelných schůzích. Jejími členy byli redaktoři muzejních odborných časopisů a toto kolegium mělo za úkol řešit všechny otázky související s vydáváním muzejních publikací. Stanovovala také každoroční ediční plány a bděla nad jejich dodržováním.

Některá muzejní periodické tisky ( $\mathrm{v}$ dnešním chápání věci se jednalo o sborníky) se běžným pravidlům vymykala. Jednalo se především o Acta entomologica, Acta faunistica a méně striktně také Annals of the Náprstek Museum a Anthropological papers of the Náprstek Museum. Společné těmto sborníkům bylo to, že stati byly publikovány zásadně v cizích jazycích, publikování v nich bylo otevřeno nejen zaměstnancům vydavatelské instituce, ale také zahraničním odborníkům, pokud se jejich texty nějak dotýkaly sbírek NM. Vydavatelem i nakladatelem bylo Národní muzeum, publikování v nich bylo honorováno a dbalo se také na jejich kvalitní grafické ztvárnění. Na rozdíl od ostatní periodické produkce nebyly tyto tituly $\mathrm{v}$ žádném případě distribuovány standardní cestou prostřednictvím PNS, i autoři se museli spokojit víceméně pouze se separáty. Pokud už se přikročilo k prodeji jednotlivých kusů, tak zásadně na fakturu přes účtárnu NM. Snahou bylo uchránit co největší část nákladu pro meziinstitucionální knižní výměnu, která zabezpečovala největší přítok zahraniční literatury př́islušného zaměření, na kterou by jinak musely být vynakládány cenné devizy. V př́padě Annals Náprstkova muzea byl učiněn drobný ústupek v tom, že byl tisk prodáván u pokladny tohoto oddělení. Toto opatření vydrželo až do roku 1983, kdy kvůli značným skladovým zásobám bylo přikročeno $\mathrm{i} \mathrm{k}$ běžnému prodeji obou přírodovědných titulů..$^{27}$

K udržení vysokého standardu kvality tištěné produkce měly být nejpozději od počátku 80. let (pravděpodobně však tato praxe byla běžná již v dřívější době, což však nemůžeme z dochovaných pramenů spolehlivě doložit) všechny knižní publikace podrobeny dvěma oponentským posudkům, časopisecké studie pak alespoň jednomu. ${ }^{28}$

Koncepce muzejních časopisů byla takřka jednotná, pochopitelně s příslušnou oborovou specializací - jejich hlavním zájmem byly muzejní sbírky a výsledky práce s nimi. Autoři přicházeli $\mathrm{z}$ různých institucí - celá řada jich byla zaměstnanci Muzea, ale postupně přibývali i autoři z jiných institucí (podobně jako členové redakčních rad). Většina časopisů byla otevřena i autorům-cizincům a texty byly publikovány i v cizích jazycích, od čehož byl očekáván především zvýšený ohlas v zahraničí. Nicméně i ty časopisy

\footnotetext{
${ }^{26}$ ANM, f. RNM, Sekretariát GǨ, 1989, Návrh Jaroslava Čechury a Vlastimila Vondrušky, 15. 2. 1989.

${ }^{27}$ ANM, f. RNM, Sekretariát GŘ, 1983, Zápis z porady o výměně Acta entomologica a Acta faunistica 25. 11. 1983.

${ }^{28}$ ANM, RNM, ŘNM 1982, Připomínky MK ČR k předloženému edičnímu řádu NM, 15. 7. 1982.
} 


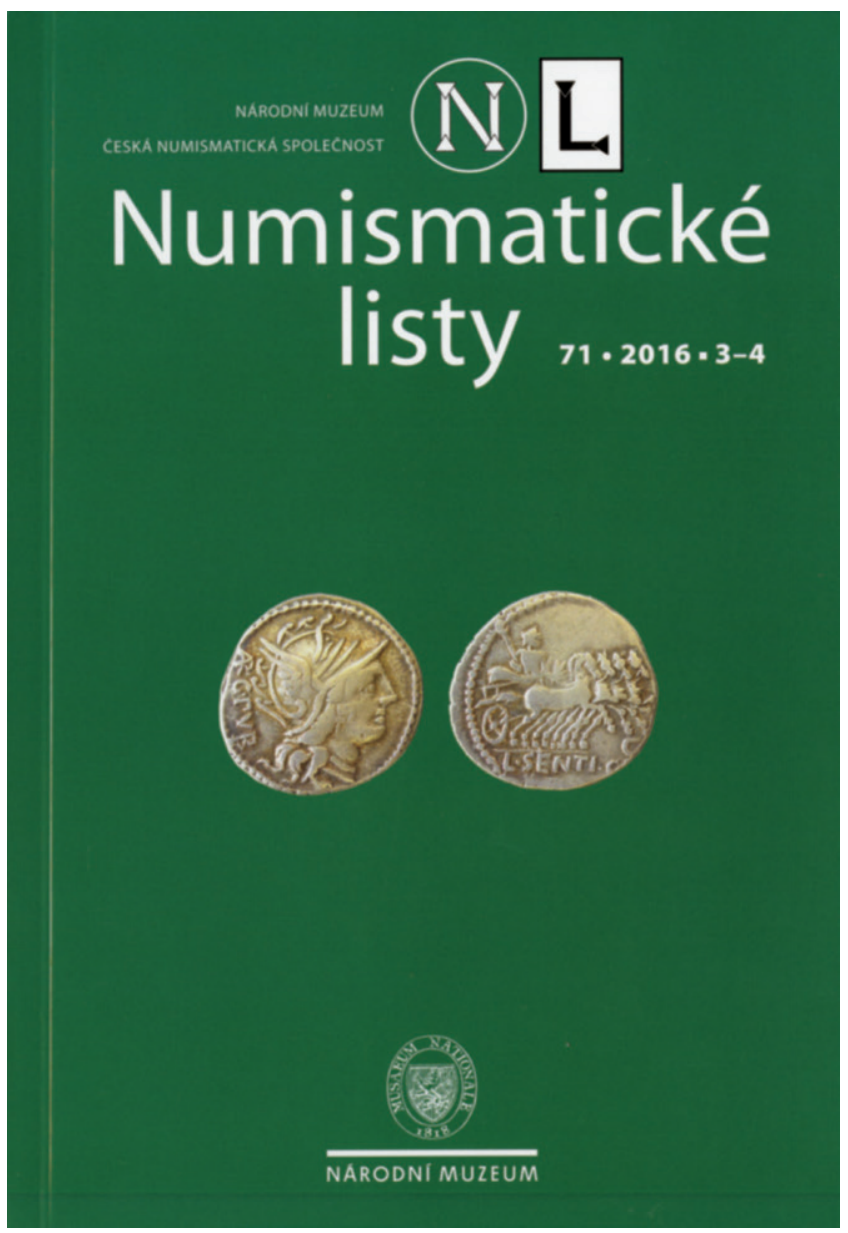

Obr. 7. Numismatické listy představují príklad časopisu, na jehož vydávání se již několik desetiletí s Národním muzeem podílí významná oborová společnost - Česká numismatická společnost.

a sborníky, které vycházely $\mathrm{v}$ češtině, obsahovaly důsledně cizojazyčná resumé pro zahraniční zájemce.

Mluvíme-li o autorech $\mathrm{z}$ řad muzejních zaměstnanců, položme si ještě další otázku - a sice, existoval-li tlak na to, aby muzejníci publikovali právě na stránkách svých domácích časopisů. Nepodařilo se najít žretelné stopy po autorském ,př́ímusu“, nicméně i přes to, že v NM byla publikačních možností skutečně celá řada, tak někteří špičkoví zaměstnanci, jejichž výsledky se NM chtělo zejména chlubit, jich naprosto nevyužívali. Jedním z takových byl např́iklad věhlasný antropolog profesor Emanuel Vlček (v NM působil v letech 1967-1991), jehož publikační pasivita na stránkách muzejních časopisů byla dokonce probírána opakovaně na zasedáních ediční rady NM. ${ }^{29}$ Zaměstnancům NM nebyla pochopitelně zapovězena ani možnost publikovat mimo svoji domovskou instituci (doma či v zahraničí), nicméně $\mathrm{v}$ určitých obdobích to bylo možné pouze s povolením přímých nadřizených i svolením ředitele NM. Př́islušná povolení se podařilo nalézt v letech 1980, 1981 a 1987 a všechna jsou kladná, nicméně je otázkou, zdali případná zamítavá stanoviska byla vyjádřena touto př́mou formou, a nikoli např. spíše zákulisními cestami. Je také zřejmé, že běžnou součástí publikační praxe byla autocenzura. ${ }^{30}$

Znamenalo publikování v muzejních periodicích pro autory alespoň drobný finanční bonus $\mathrm{k}$ výplatě? Jak v kterém časopise - publikování v obou řadách ČNM a třech řadách Sborníku honorováno nebylo, naopak Acta entomologica, Acta faunistica a Annals of the Náprstek Museum platily štědře (až 1200 Kč za autorský arch v 70. letech 20. století) $)^{31}$ $\mathrm{s}$ tou výminkou, že autoři si měli z honoráře zaplatit i jazykovou korekturu, pokud byl článek tiš̌těn cizojazyčně. ${ }^{32}$

Komplikované financování tisku časopisů i jiných publikací v Muzeu v první polovině 20. století bylo již nastíněno výše: Acta entomologica byla financována z Nickerlova fondu (který představoval poměrně jistý zdroj prostředkủ), na Muzejník přispívalo NM a jinak byla jeho agenda i financování na Matici české, výroba a distribuce Sborníku NM byly financovány ze subvencí země České a jeho zajištění bylo tedy nejméně jisté, nebot' o př́slušnou podporu bylo třeba žádat vždy znovu a záruky pro její obdržení ve špatné hospodářské situaci prakticky neexistovaly. Situace se stabilizovala $\mathrm{v}$ poválečném období, po postátnění NM v roce 1949 a zejména po roce 1955, kdy se NM stalo př́spěvkovou organizací ministerstva kultury. V rozpočtu se od té doby pravidelně objevovala stabilní částka alokovaná na ediční počiny instituce. Finanční pokrytí vydavatelské činnosti tedy v podstatě závažný problém nepředstavovalo, byt' náklady na tisk byly poměrně značné vzhledem $\mathrm{k}$ tomu, že v podstatě jedinou technologií, která se ve 2. polovině 20. století k výrobě časopisů použivala, byl knihtisk (později zcela výjimečně ofset).

Jistě by bylo velmi zajímavé podívat se na konkrétní částky, které NM vynakládalo na vydávání svých časopisů, a sledovat jejich vývoj v dlouhodobém horizontu. $\mathrm{V}$ této otázce však narážíme na torzovitost dochovaných pramenů z období první republiky a jejich nezpracovanost $\mathrm{v}$ období následujícím. ${ }^{33}$ Celá problematika je navíc komplikována tím, že $\mathrm{v}$ různých letech vycházel vzhledem ke zpoždění různý počet čísel jednotlivých periodik.

Stabilní financování ovšem znamenalo nutnost dodržovat určitá pevná pravidla při př́pravě jednotlivých titulů. Tak předně časopisy měly stabilní, pevně stanovený stránkový rozsah a stanoven byl také objem prípadných obrazových př́loh.

Zajímavou otázkou je, v jakých nákladech byly jednotlivé časopisecké tituly vydávány. $Z$ dnešního hlediska můžeme říci, že byly poměrně vysoké. Vynikaly zejména Numismatické listy (více 4370 kusů), ovšem s tou výminkou, že takto vysokým počtem výtisků bylo třeba uspokojit

\footnotetext{
${ }^{29}$ ANM, f. RNM, Sekretariát GǨ, 1981, Zápis ze schůze Ediční rady NM ze dne 4. 6. 1981: „Napřiklad dr. Vlček nepublikuje ani v př́rodovědných, ani historických časopisech... “, v originále dokonce podtrženo, Zápis ze schůze Ediční rady konané dne 30. 7. 1981.

${ }^{30}$ Př́íslušné konvoluty povolení jsou zachovány v daných letech ve složkách týkajících se ediční agendy ve fondu RNM, Sekretariát GŘ.

${ }^{31}$ Dle historických údajů Českého statistického úřadu se jednalo takřka o polovinu hrubého měsíčního př́imu osob zaměstnaných v této sféře. Srv. historické tabulky na https://www.czso.cz/documents/10180/60664312/1100251839.pdf/a531d6c1-596c-4b86-8993-3121aa823baa?version=1.0/accessed 2020-04-27/.

${ }^{32}$ Sazba honoráře platila pro československé badatele, zahraniční měli dostat honorář pouze v tom případě, že osobně přijeli bádat do Národního muzea do jeho sbírek.

${ }^{33}$ Jistou vypovídací hodnotu mají pro starší období archiválie Matice české, které však daleko podrobněji nežli náklady na výrobu časopisů reflektují distribuci časopisu. Materiály muzejní účtárny a později ekonomického oddělení jsou dosud zcela nezpracované.
} 
všechny členy České numismatické společnosti, pro něž sloužilo toto periodikum jako členský časopis. Časopis tak na jedné straně měl zajištěný odbyt, na straně druhé ovšem jeho výroba byla pro NM i značným materiálním břemenem. Nejvyšší náklad z ostatních periodik měla Muzejní a vlastivědná práce (1900 ks), což souvisí s její širokou distribucí garantovanou zájmy Muzeologického kabinetu. Obě řady Muzejníku a většina dalších periodik i sborníků byla vydávána v počtu mezi 1200 a 1000 kusů každého čísla. Poněkud nižší náklad měly všechny tři řady Sborníku (mezi 600 až 800 kusů). Ke konci 80. let a na počátku let 90. (v 8. pětiletce) se mělo jít jednoznačně cestou racionalizace a úspor - snižování nákladu všech periodik s ohledem na jejich odbytový potenciál. ${ }^{34}$

Velkou kapitolou muzejních periodik zůstává také jejich šířením doma i v zahraničí. Standardních cest distribuce muzejních časopisů bylo několik. Jako nejefektivnější se ukazovala meziknihovní výměna. Skutečně, polovina nákladu většiny periodik směřovala do domácích, ale především do zahraničních knihoven. Výměna za jinak obtížně dostupné zahraniční publikace byla snad největším benefitem, který kompenzoval celou řadu technických obtíží při muzejní vydavatelské činnosti a také nemalé finanční náklady s ní spojené. Jak ukazují v 80. letech pravidelně vyhotovované přehledy, výměna měla aktivní saldo, Muzeum tedy získávalo více, než samo do zahraničí posílalo, a to jak z hlediska počtu svazků, tak i v objemu vynaložených financí. ${ }^{35}$ Běžným předplatitelům dodávala časopisy Poštovní a novinová služba (desítky až stovky výtisků), do zahraničí pak časopisy putovaly prostřednictvím agentur zahraničního obchodu Artia či Magnet (až na výjimky pouze jednotliviny).

\section{Problémy ediční praxe Národního muzea}

I přes to, že Muzeum mělo ve vydávání tištěné produkce, periodické i neperiodické, opravdu dlouholetou praxi, nebyla tato činnost bezproblémová. Mohlo se jednat o drobné každodenní obtíže editorské praxe, v některých případech se jednalo o zcela zásadní komplikace, které mohly v důsledku zapříčinit i zánik muzejní časopisecké produkce.

Klasickým drobným steskem redaktorů časopisů vždy byla a dodnes je nekázeň autorů, kteří dodávají rukopisy se značným zpožděním, a není tak možno dodržet výrobní lhůtu časopisu. Podobné stesky se objevují v zápisech z ediční rady NM celkem pravidelně, ovšem většinou se týkají spíše vydávání monografií či katalogů, ve srovnání s jinými překážkami, které bylo nutno v souvislosti s vydáváním časopisů čelit, se však jednalo o v podstatě nevinné hříčky.

Daleko závažnější byly však technické problémy a nedostatek surovin. Např́klad v letech 1968-1970 nevyšla historická řada Časopisu NM. Pokud chceme tuto skutečnost interpretovat, na první pohled se nabízí, vzhledem $\mathrm{k}$ uvedenému období, že se tak mohlo stát vinou politických čistek

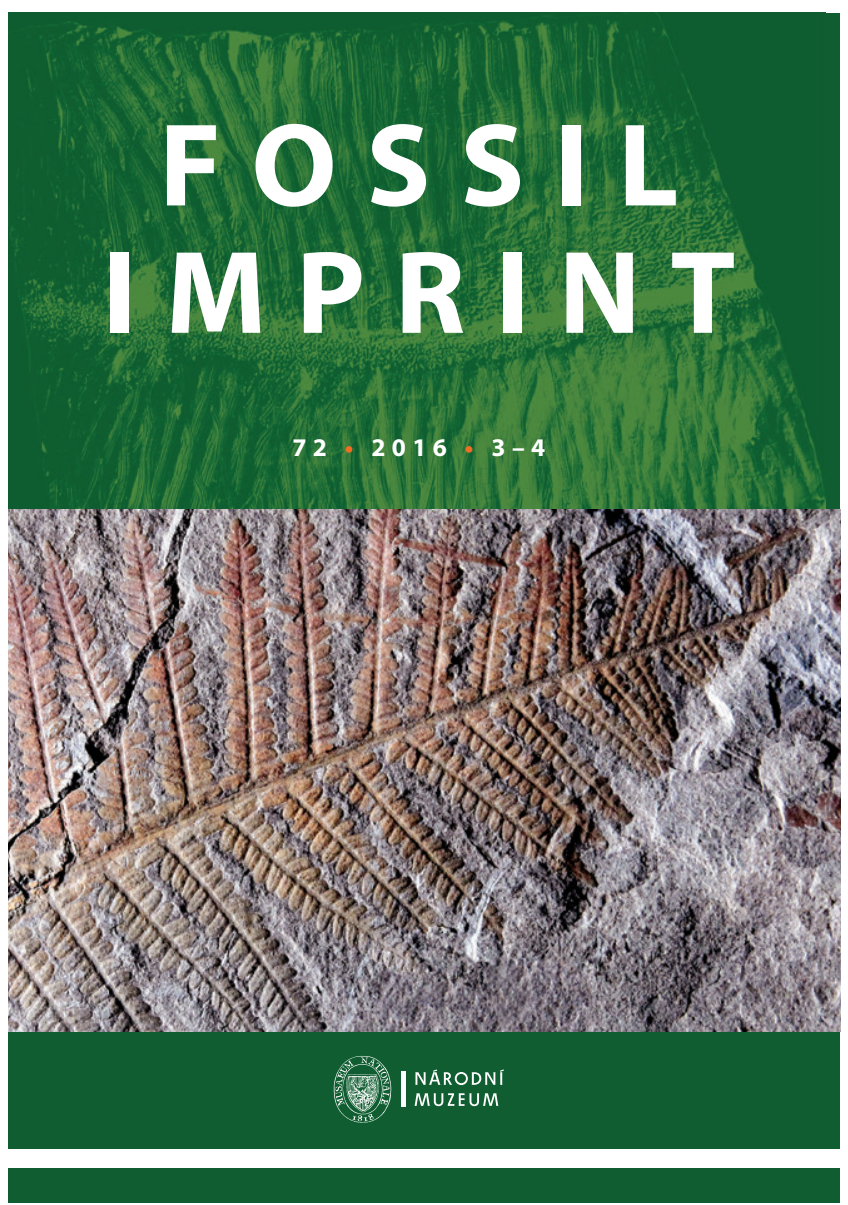

Obr. 8. Př́rodovědné časopisy si udržují tradičně vzhledem ke svému odbornému zaměření velice dobré postavení i na mezinárodním fóru. Příspěvky v nich jsou publikovány v cizích jazycích a některé $z$ nich přizpůsobily tomuto trendu i svůj název. Jedním z príkladů je Sborník Národního muzea v Praze - řada B, prírodní vědy, který se od roku 2016 úzce specializuje na práce $z$ oblasti paleontologie a príbuzných disciplin a také v souvislosti s tím změnil svůj název na Fossil Imprint.

v Národním muzeu, at' již v redakci, či mezi autory. Zdá se však, že problém spočíval jinde, a sice v nedostatku tiskárenské kapacity. Podobně způsobilo výpadek ve vydávání přírodovědné řady téhož časopisu, když havlíčkobrodské tiskárny vypověděly od třetího čísla roku 1984 jeho tisk a ředitel NM Adolf Čejchan marně hledal náhradu (ještě první číslo roku 1985 se podařilo vyrobit kooperací závodu Polygrafia, závod 03, který byl ke složitým matematickým a chemickým sazbám jako jediný vybaven). Ve zdůvodnění stálo, že nové sázecí stroje pro fotosazbu neobsahují řeckou abecedu, značky, vzorce a indexy, a tudíž není možno náročnou technickou sazbu provádět. ${ }^{36}$ Tento problém se pak ukázal jako dlouhodobý a nebyl uspokojivě vyřešen ani v roce 1986 a ediční rada $\mathrm{v}$ tomto roce dokonce odsouhlasila, aby NM vstoupilo do arbitráže se svým „dvorním“ nakladatelem, nakladatelstvím Panorama. ${ }^{37}$ Poslední číslo tak vyšlo v roce 1985 a muzeu se

\footnotetext{
${ }^{34}$ ANM, f. RNM, Sekretariát Ǧ̌, 1985, Vyhodnocení publikační činnosti NM, připomínky ředitele NM, 18. 10. 1985.

${ }^{35}$ ANM, f. RNM, Sekretariát GR̆, 1985 a 1986 passim.

${ }^{36}$ ANM, f. RNM, Sekretariát GŘ, 1983, Dopis ředitele NM řediteli nakladatelství Panorama, 20. 6. 1983 a další související korespondence k této věci S MK ČSR.

${ }^{37}$ ANM, f. RNM, Sekretariát GŘ, 1986, Zápis z ediční rady Národního muzea, která se konala dne 27. října 1986, bod III/2.
} 
komplikovala zahraniční výměna. ${ }^{38}$ Nedostatečná kapacita přikázaných tiskáren pak zpožd'ovala či zcela hatila výrobu publikací i v dalších letech, takže koncem 80. let NM např. upustilo od tisku všech publikací mimomuzejních autorů. ${ }^{39}$

Tisk periodik byl také nakonec, vzhledem k závazku mezinárodní výměny, jedinou publikační jistotou Národního muzea. ${ }^{40}$ Slovy náměstka ředitele NM, předsedy ediční rady a ředitele knihovny NM Jaroslava Vrchotky: ,Zadat titul tzv. merkantilního tisku je totiž pro NM, na rozdíl např. od Národniho divadla, které má vyhrazenou jednu tiskárnu jen pro svou potřebu, anabázi pracovniků VOÚ, která konči úspěšně většinou jen zásluhou osobních známostí. "41 Situace nakonec byla natolik zoufalá, že NM uvažovalo již od roku 1968 o pořízení vlastní tiskárny. Mělo jít o zařízení v Hostinném v Podkrkonoší, pro vysoké náklady a četné administrativní překážky se však akvizici nepodařilo dotáhnout ke zdárnému konci a NM čekalo několik dalších desetiletí obtížných bojů o získání tiskárenských kapacit. ${ }^{42}$

Se železnou pravidelností se také v záznamech z jednání z ediční rady objevují stesky nad nedostatkem papíru, které trvají víceméně celou 2. polovinu 20. století. Právě na něm nakonec ztroskotala celá řada aktivit směřující k rozšíření časopiseckých titulů (a nejen těch) vydávaných NM. Vyjednávání s ministerstvem kultury o jakémkoli navýšení nákladu časopisů či vzniku nového titulu bylo podmíněno tím, že si NM sežene na vlastní náklady a vlastním přičiněním pro tento počin papír. Vzhledem $\mathrm{k}$ tomu, že se tuto podmínku pravidelně nedařilo splnit, jednání vyznívala většinou do ztracena. Opakovaně bylo tudíž apelováno na jednotlivé redakce $\mathrm{i}$ autory, aby se nenavyšoval stránkový objem publikací, protože potom nezbýval papír na další publikace. ${ }^{43}$ Pro úplnost je ovšem třeba dodat, že potíže s nedostatkem papíru i tiskárenských kapacit byly dobově charakteristické a v žádném př́ipadě nebyly pouze specialitou Národního muzea.

Zcela tradičním problémem, s nímž se ostatně Muzeum potýká dodnes, je zajištění dostatečného odbytu vydávaných titulů. V případě periodik nebyl problém tak palčivý, velká část nákladu se rozptýlila po republice i mezi zahraniční partnery prostřednictví výměny, kterou pro větší část oddělení realizovala muzejní knihovna (výjimku představovala exkluzivní cizojazyčná periodika, která měnila přímo příslušná odborná oddělení a tiskoviny Vědecko-osvětového útvaru), či předplatného. Propagační tisky, katalogy, některé monografie a postupem času i časopisy se hromadily ve skladech a představovaly dvojí problém - první byl problém ekonomický, protože rostoucí skladové zásoby neprodaných publikací zhoršovaly bilanci hospodaření NM ve výkazech pro nadřízené instance, druhý problém byl samozřejmě v tom, že NM tisklo své katalogy a další produkci především proto, aby se dostala co nejširšímu okruhu zájemců - a k tomu zjevně nedocházelo.

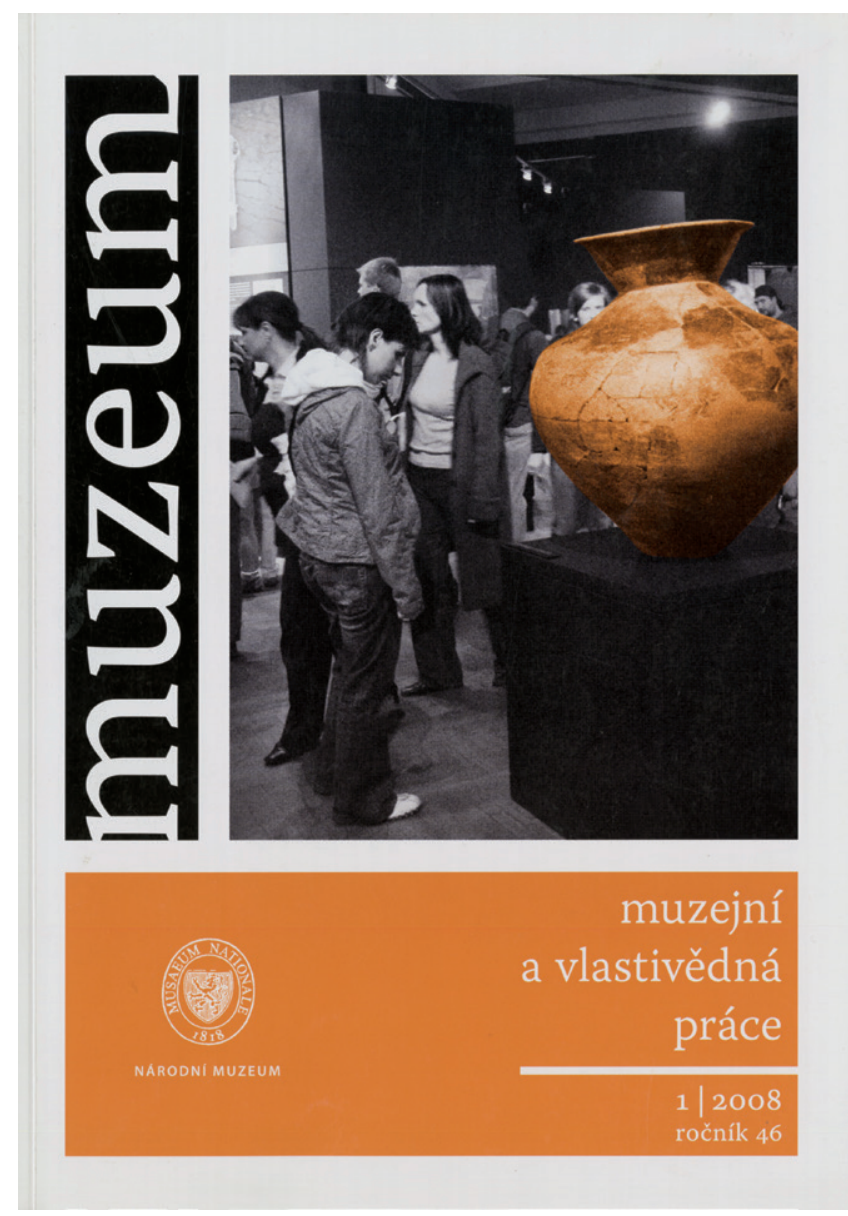

Obr. 9. V roce 1963 převzalo Národní muzeum, resp. jeho Muzeologický kabinet vydávání Časopisu Společnosti přátel starožitností (pod různými názvy vydáván již od roku 1893) a pod jménem Muzejní a vlastivědná práce jej přetvořilo na oficiální časopis československé socialistické muzeologie. V roce 2008 se oba časopisy opět rozdělily na dvě samostatná periodika: Časopis Společnosti prátel starožitností a Muzeum / Muzejní a vlastivědná práce.

Na vyřešení ekonomické stránky věci tlačilo vedení NM v prostředí plánovaného hospodářství a pečlivého výkaznictví celá 80 . léta 20 . století, víceméně bezúspěšně: jsme svědky účetních převodů a účelových změn statusu nashromážděných publikací (takovým řešením byl např. jejich převod do fondu učebních pomůcek či přeceňování). ${ }^{44}$

Skutečně zabezpečit odbyt svých publikací se vedení NM pak snažilo na jedné straně jednáním s knižním velkoobchodem, který měl část produkce nabízet ve své síti prodejen Kniha a Antikvariát. Problémy takové spolupráce byly ovšem značné - jednak Kniha i Antikvariát požadovaly poměrně značný rabat (30, resp. $55 \%$ ), nejasné byly některé účetní záležitosti a nakonec to znamenalo i práci

\footnotetext{
${ }^{38}$ ANM, f. RNM, Sekretariát GŘ, 1988, Korespondence ředitele NM a generálním ředitelem Polygrafického průmyslu v květnu 1987.

${ }^{39}$ ANM, f. RNM, Sekretariát GŘ, 1985, Zápis ediční rady Národního muzea, která se konala 21. 11. 1985.

${ }^{40}$ ANM, f. RNM, Sekretariát GŘ, 1985, Vyhodnocení publikační činnosti NM, připomínky ředitele NM, 18. 10. 1985: ,současné ekonomické podminky ústavu a resortu umožňnuji jen vydáváni periodických publikací, přičemž vydávání ostatních bude ř ešeno individuálně".

${ }^{41}$ ANM, f. RNM, Sekretariát GR̆, 1986.

${ }^{42}$ ANM, f. RNM, Sekretariát GŘ, 1968/3, Zápis č. 7 z porady vedení Národního muzea konané dne 5. 8. 1968.

${ }^{43}$ ANM, f. RNM, Sekretariát GR̆, 1981, Př́ípis ředitele NM Federálnímu úřadu pro tisk a informace, 15. ledna 1981, Zápis ze schůze Ediční rady konané dne 30. 7. 1981, bod 3, srv. i tamtéž, rukopisný př́ípis VOU na Stav edice zásob Fontes Archeologici pragenses ke dni 31. 12. 1981.

${ }^{44}$ ANM, f. RNM, Sekretariát GŘ, 1981, Zápis ze schůze Ediční rady NM ze dne 4. 6. 1981; ŘNM 1985, Stanovisko k návrhu NpM, 26. 9. 1985, kde se jedná konkrétně o značné zásoby sborníku Annales.
} 
navíc, protože již vytištěné publikace měly být označovány razítkem cenou a „sedmimístným čislem, které nám nadiktují, protože Knižní velkoobchod je celý postaven na počitači “. ${ }^{45} \mathrm{Na}$ druhou stranu napřr. starší propagační materiály či starší čísla časopisů se měly zdarma rozdávat při nejrůznějších př́ležitostech (přednášky, vernisáže atd.). ${ }^{46}$ Až v roce 1986 se objevil pokus vejít v jednání s redakcí časopisu Nové knihy, aby byly nové muzejní publikace tímto periodikem anotovány. ${ }^{47}$ Praktické dopady všech těchto opatření však nebyly až do konce sledovaného období příliš výrazné.

Připomeňme ještě jednou periodika, která vydávalo Muzeum ve spolupráci s odbornými společnostmi. Obě periodika tak měla na rozdíl od ostatních zcela zaručený odbyt celého poměrně značného nákladu, ovšem, jak se ukázalo v průběhu doby, toto sepětí se mohlo stát pro NM i značným břemenem. V 80. letech totiž pravidelně $(1980,1986)$ Numismatická společnost upomínala NM o zvýšení nákladu Numismatických listi̊, protože náklad nepokrýval její potřebu časopisu jako členského periodika. ${ }^{48}$ Tehdejš́ ř ředitel NM Adolf Čejchan se nakonec nedomohl navýšení přiděleného množství papíru a tiskárenských kapacit a uvažoval dokonce o snížení nákladu ostatním časopisům, aby bylo možno smlouvě s Numismatickou společností dostát a zvýšit náklad Numismatických listů o požadovaných 500 kusů.

\section{Závěr}

Národní muzeum v éře Československa prošlo výraznou modernizací všech aspektů své existence a vydávání odborných monografií, př́ležitostných tisků a odborných časopisů nebylo výjimkou. Připomeňme několik významných aspektů posledně zmíněné aktivity.

Do druhého století své existence v roce 1918 vstupovalo NM s jediným časopisem (Časopisem Národního muzea) vycházejícím ve dvou řadách specializovaných na př́rodní a historické vědy. Během první republiky obohatilo portfolio muzejních časopisů periodikum zaměřené na entomologii a také další časopis se dvěma specializovanými řadami, Sborník Národního muzea, jehož obsah měl být vědečtější, nežli byl v té době obsah ČNM. Prohloubení oborové specifikace jsme pak svědky především ve 2. polovině 20. století, nicméně některé muzejní obory se svých speciálních časopisů dočkaly až zcela $\mathrm{v}$ nedávné době (časopis Musicalia vznikl až v roce 2009).

Ve sledovaném období prošly změnami i vnitřní mechanismy řízení muzejních časopisů - ostatně tomu tak bylo i v časopisech vydávaných jinými institucemi. Od monokratického řízení časopisů se pokročilo ke jmenování kolektivních orgánů (redakčních rad či redakčních kruhů), zprvu tvořených především zaměstnanci NM, později rozšířených i o mimoinstitucionální odborníky. Jmenovat také zahraniční členy rad nebylo v období do roku 1989 obvyklé. Důsledně se také začalo prosazovat posuzování odborné kvality předkládaných textů. Od počátku 70. let 20. století se pravidelně scházela ediční rada NM, která garantovala průběh vydávání všech tištěných výstupů z NM.

Poválečná doba však přinesla do vydávání časopisů i některé obtížně řšsitelné technické problémy, a sice nedostatek papíru a tiskařských kapacit, které byly příčinou často několikaletého zpožd'ování vydání muzejních časopisů a generovaly i další obtíže, napřs. při mezinárodní knižní výměně a plánování financování a odbytu publikací.

Muzeu se i přes tyto obtíže udržet svou odbornou časopiseckou produkci až do konce 80 . let minulého století a dokázalo ji bez výraznějších ztrát provést i komplikovanými a mnohdy i nepřehlednými časy následujícího desetiletí. $\mathrm{S}$ odstupem dalších dvou desetiletí můžeme konstatovat, že odborné časopisy NM obhájily úspěšně svou existenci i v globálním vědeckém prostředí, prrizpůsobily své standardy nejmodernějším požadavkům a staly se součástmi významných databází. Šíře portfolia muzejních periodik vydávaných v současné době o tom konečně podává více než výmluvné svědectví. ${ }^{49}$

\footnotetext{
${ }^{45}$ ANM, f. RNM, Sekretariát GŘ, 1981, Záznam z porady s pracovníky knižního velkoobchodu, 8. 6. 1981.

${ }^{46}$ ANM, f. RNM, Sekretariát GŘ, 1980, Zápis z porady o opatřeních směřujících ke snížení zásob publikací NM určených k prodeji, 22.10 .1980$. V této souvislosti se hovoří, byt' v uvozovkách, př́ímo o „,zbavováni se “př́slušných tiskovin.

${ }^{47}$ ANM, f. RNM, Sekretariát GR, 1986, Zápis z ediční rady Národního muzea, která se konala dne 27. října 1986, bod 3.

${ }^{48}$ ANM, f. RNM, Sekretariát GR̆, 1980, Korespondence ředitele NM s nakladatelstvím Panorama, 24. 9. 1980, 30. 10. 1980. ŘNM 1986, Zápis z ediční rady Národního muzea, která se konala dne 27. ř́jna 1986.

49 Srv. https://publikace.nm.cz/publikace.php /accessed 2020-04-27/.
} 